\title{
Good Pedagogical Practices in Science Teaching
}

Buenas prácticas pedagógicas en la enseñanza de las ciencias

Research article | Artículo de investigación

Received on: July 26th 2018 Accepted on: August 21st 2019

Available online from: July 2021

doi: 10.11144/Javeriana.m14.gpps

Pedro Aurelio Sotomayor-Soloaga pedro.sotomayor@uda.cl

Universidad de Atacama, Chile (D) ORCID: https://orcid.org/0000-0002-9143-8280 


\section{Abstract}

This research emphasize the importance of science and science education as pillars of development and social progress. A case study of three science teachers, evaluated as outstanding by the Inquiry-based Science Teaching Program, aimed to respond the question: What characterizes good pedagogical practices in science education? Based on a qualitative approach and techniques, such as classroom observation and in-depth interviews, results show a characterization of the pedagogical practices carried out by teachers, highlighting both their practical and reflective dimensions.

\section{Keywords}

Primary school teachers; science education; teaching practice

\section{Resumen}

Enfatizando la importancia de las ciencias y de la educación en ciencias como pilares del desarrollo y progreso social, se presenta un estudio de caso de tres profesoras de ciencias evaluadas como destacadas por el Programa de Enseñanza en Ciencias Basado en la Indagación, cuyo objetivo era responder la pregunta: ¿Qué caracteriza las buenas prácticas pedagógicas en educación en ciencias? Basado en un enfoque cualitativo y técnicas como la observación de aula y entrevistas en profundidad, los resultados muestran una caracterización de las prácticas pedagógicas que llevan a cabo las docentes, destacando tanto su dimensión práctica como reflexiva.

\section{Palabras clave}

Profesor de primaria; enseñanza de las ciencias; práctica pedagógica 
Article description | Descripción del artículo

Research article derived from the project Pedagogical

Interactions and Higher-Order Thinking: A Proposal

for Teacher Reflection.

\section{Introduction}

Science and technology are fundamental pillars of the social, economic and cultural development of society, as they are necessary ways to understand the changes that are taking place in our society and the effects that will inevitably have on its development, in the intellectual independence of its protagonists, and in the exercise of the freedom of human beings (Allende et al., 2005). Therefore, scientific competence is considered as one of the fundamental key competences in young people's education to navigate current societies, where a good part of the situations and problems faced require a certain degree of knowledge about science and technology (Gil, 2017).

In this context, the Chilean scientific community has taken the responsibility of collaborating with the improvement of science education, in terms of its quality and relevance. However, this becomes alarming when, despite this emphasis, the progressive disinterest of students in this branch of knowledge is evident, this phenomenon has been called "the current crisis in science education" (Acevedo et al., 2005). Fernández-González (2008) examines why studying science is not attractive to many students, and argues that a good part of the responsibility falls on the approach of its teaching, since it continues to be self-centered, academic and formal; furthermore, science teaching lacks a connection between the science that is present in the everyday world or with the non-formal science of the media. A science that does not attend (or very little) to basic epistemological aspects (Fernández-González, 2008).

Moreover, the results of the application of the TIMSS Test in 2015 reveal that, depending on the grade and subject, between $15 \%$ and $37 \%$ of the student body in Chile do not reach the minimum threshold associated with the level of low performance (compared to $5 \%$ and $16 \%$ internationally, respectively), and the advanced level is only reached by $1 \%$ of the students of the country, compared to approximately $7 \%$ internationally (Agencia de la Calidad de la Educación, 2015).

Accordingly, "the scientific-technological transformations that society is facing require rethinking the objectives of the current scientific education" (Strieder et al., 2017), therefore, the different efforts should point 
towards ending the focus of the field, whose knowledge is restricted to those who work in the scientific-technological field, in order to turn science into a field of knowledge accessible to all. This process of scientific literacy requires a reformulation of the concept and its way of teaching-learning science, so that students can know and understand its content, develop skills and acquire the ability to project their learning to different situations and contexts (Devés \& Reyes, 2007).

This new way of accessing science by students does not constitute a recipe whose results are obtained by themselves, but is mediated and regulated by teaching action. Harlen (1999) highlights the central role of teachers in the development of research activities and understanding of the concepts of science, which implies facilitating the work of argumentation, dialogue and group discussion, as well as foreseeing direct exploration with materials.

In this sense, this work aims to answer the question: What characterizes good pedagogical practices in science education? This question is relevant in a context in which learning must take place in a new form of pedagogical work, where students are at its center, including their characteristics and previous knowledge, and which requires the development of different pedagogical strategies adapted to the different rhythms and learning styles of a heterogeneous student body. Within this context there is the need to reorient school work from its current, predominantly based on lectures and normative forms, to a new way of teaching based on exploration activities, search for information and construction of new knowledge led by students, both individually and collaboratively, and as a team (Rosas \& Sebastián, 2008, cited in Manríquez, 2014).

Pedagogical practices have been the focus of various research studies focused on how to teach students and how knowledge is constructed. In this regard, authors such as Chirinos \& Padrón (2010) highlight the teachers' concern about improving their pedagogical practice, relating efficiency in the classroom with excellent performance. For their part, Castro et al. (2015), in their constructivist research, emphasize the importance of pedagogical practice and the dynamics of student-teacher interaction, considering the latter as a learning guide, leaving aside the mere role of transmitter of knowledge. Daboin de Briceño (2008), specifically in the area of natural sciences, highlights the influence of pedagogical practice on the successful construction of knowledge, stating that the problem of teaching today is that it has been taken as a process of transferring new information to the individual, but it remains as a repetitive action, which is why reflection is needed to reorient, plan and stimulate the work of the teacher in the classroom. Torres \& Barrios (2009) make a comparison of the concept that 
teachers and students give to teaching-learning and the construction of knowledge in the area of natural sciences and conclude that practices are debated between innovation and traditionalism, but that it is necessary to show a clear structure during the process. On the other hand, according to Velásquez (2012), pedagogical practice should integrate into a single objective the familiarization of the student with the scientific, active and constructivist methodology, with an approach of contrasting models.

It is important to mention that at present "science pedagogy is consolidated as an autonomous research field with a high scientific production on numerous issues related to science teaching-learning" (Manchon-Gordon \& García-Carmona, 2018, p. 216). However, it has been found that the transfer of knowledge produced by didactic/teaching research of science classes is very limited, this reveals a disconnection between research and the usual teaching practice of science teachers, along with a scientific education characterized by superficial teaching approaches that is distant from the orientations suggested by didactics/teaching research, with a minimal impact on the learning of science based on the competencies demanded today (Manchon-Gordon \& García-Carmona, 2018).

\section{Conceptual Models}

Both the teaching of science and science and technology are highly linked, since they play a fundamental role in the present and in the future of our society, as essential pillars of the social and economic development of nations (Allende et al., 2005). Developing countries, where technological and scientific changes have been faster, acted in relation to this issue and introduced science into the curriculum in primary education (Harlen \& Allende, 2009), as science education allows students to analyze and question things, as well as question established truths and respect other's point of view (Charpak et al., 2006).

In this regard, although the child has the capacity and motivation towards exploration and inquiry, according to Harlen \& Allende (2009), their ideas about the world that surrounds them are built during the first years of primary school, regardless of whether they were taught science or not. Therefore, it is necessary to incorporate the teaching of science in early stages of development, to promote the use of a scientific approach in the process of exploring the world, motivating the interest of observing natural phenomena, the ability to formulate explanatory hypotheses of the phenomena that are observed, together with the design and execution of experimental procedures that allow discarding or confirming the formulated hypotheses (Allende et al., 2005). 
This relationship, which at the beginning would be closely generated between children and science, would be interrupted when starting their formal education, since the child would be distancing from a world of experiences, facing "the reality of the unknown, dogmas and rote learning "(Charpak et. al., 2006, p. 3). Students not only encounter conceptual difficulties, but they also experience problems using reasoning and problem-solving strategies that are typical of the scientific work. On the other hand, transfer of knowledge would not be entirely correct, since children would know how to do things, but would not understand what they are doing, and therefore they would not be able to explain or apply them to new situations. "These difficulties are evident particularly in problem-solving situations, which they tend to confront in a repetitive way, as simple routine exercises, instead of seeing them as open tasks that require reflection and decision-making processes from their part" (Pozo \& Gómez, 2004, p. 20).

Harlen (1999) argues that given the various causes and difficulties that could be affecting the optimal development and implementation of science teaching, this process should involve the ideas, imagination and children's activities in their development, which in turn will only work if the teacher is convinced of the value of applying this mode of teaching. Making this change implies that teachers must be convinced that science is a powerful tool for the development of children's creative potential, however, that success will only be achieved if teachers manage to engage students with a clear mastery of its content and rigorous preparation of each of the activities they carry out (Allende et al., 2005).

The privileged space to approach this challenge occurs in the context of pedagogical practices, understanding them as a

social, objective and intentional praxis in which the meanings, perceptions and actions of the agents involved in the process intervene - teachers, students, educational authorities, and parents - as well as the political, institutional, administrative, and normative aspects, which according to the educational project of each country, define the role of the teacher (Fierro et al., 1999, p. 21).

Hence, a pedagogical practice is understood as everything that happens in the classroom, influenced by the personal biography, education and social beliefs of the teacher, which positively or negatively affect the experience of students.

A broader view of the concept of pedagogical practice is provided by Angulo \& Álvarez (2010), who understand it as that practice that not only involves teachers in their work, but also the pedagogical praxis as a reflective 
exercise of both the teaching processes and learning processes. They continue to argue that it also constitutes a privileged academic space to bring teachers closer to the problems they must address with students, providing them with the tools to successfully intervene in complex educational scenarios.

On the other hand, Rojas \& Zapata (2017) pointed out that the main objective of pedagogical practices is to contribute to the teacher's professionalism, disciplinary education and the understanding of the influence of the school context on education. The professionalism of the science teacher is the objective attributed to the pedagogical practice for the construction of the professional knowledge of science teachers (CPPC).

These same authors, based on the works of Valbuena (2007), Gess-Newsome \& Lederman (1999), as well as Barnett \& Hodson (2001), identified fifteen components corresponding to the four knowledges that, in their opinion, are part of the CPPC.

Table 1

Components of the professional knowledge of the science teacher (CPPC)

\begin{tabular}{|c|c|}
\hline Knowledge & Components \\
\hline $\begin{array}{l}\text { Pedagogical } \\
\text { knowledge } \\
\text { (Valbuena, 2007) }\end{array}$ & $\begin{array}{l}\text { - Teaching-learning process (characteristics, factors that affect it, main obstacles, } \\
\text { strategies to facilitate it) } \\
\text { - Resource management in educational processes }\end{array}$ \\
\hline $\begin{array}{l}\text { Knowledge of the } \\
\text { context (Barnett \& } \\
\text { Hodson, 2001) }\end{array}$ & $\begin{array}{l}\text { - Science education (goals pursued by the academic community of science } \\
\text { education and environmental education) } \\
\text { - Teacher professionalism (basic teaching skills, interrelationships between } \\
\text { teachers and credibility among colleagues) } \\
\text { - Science curriculum (prescribed content and assessments) } \\
\text { - Specific school culture (locally acceptable behavior patterns) }\end{array}$ \\
\hline $\begin{array}{l}\text { Knowledge of } \\
\text { disciplinary content } \\
\text { (Gess-Newsome } \\
\text { \& Lederman, 1999) }\end{array}$ & $\begin{array}{l}\text { - Disciplinary contents (factors, concepts, principles and procedures of the discipline) } \\
\text { - Disciplinary structure (interrelation between the concepts, "sequencing") } \\
\text { - Disciplinary nature (guidelines for teaching specific content and contextual } \\
\text { influence on school implementation) }\end{array}$ \\
\hline $\begin{array}{l}\text { Didactic knowledge } \\
\text { of the content } \\
\text { (Valbuena, 2007) }\end{array}$ & $\begin{array}{l}\text { - Disciplinary contents to be taught } \\
\text { - Purposes of the discipline and its teaching } \\
\text { - Methodological strategies for teaching the discipline } \\
\text { - Students' conceptions of the discipline } \\
\text { - Difficulties in teaching-learning } \\
\text { - Assessing the learning and knowledge }\end{array}$ \\
\hline
\end{tabular}

The concept of pedagogical interaction is associated with the notion of pedagogical practice. In the context of this research, the pedagogical interactions that were established between teachers and students were considered as an instance that played a fundamental role in the development and acquisition of student's learning, and that, given their impact, had the 
power to favor, or not, the teaching of science. An adequate conceptualization would be to define a minimum unit of interaction as at least "two contiguous verbal utterances that have a symbolic relationship; this is given by the space-time coordination of two or more actions, of two or more subjects" (Velasco, 2007, p. 2).

However, this social coordination is not usually planned, it can be spontaneous, which is why this is one of the characteristics that enables communication. Although interactions are a process that goes beyond the dialogical sphere, in this case the attention is on the pedagogical practices and interactions between the teacher and the student, and vice versa, through which the teacher acts as a mediator and promoter of the constructive knowledge of the student. This process occurs through the establishment of a dialogue that encourages its development, considering dialogue as "verbal interaction between two or more subjects, characterized by the existence of turns, usually following attentive listening and open discussion, which implies inferential cognitive processes of an individual and social nature, as well as the opinion of participants" (Aguilera, 2000).

\section{Methodology}

\section{Methodological Approach}

This is a qualitative research study, defined as a research process that, based on different methodological traditions, focuses on understanding phenomena, building a complex global picture conducted from a natural stage (Creswell, 1998). Regarding the design, and following the classification of Rodríguez et al. (1999), a single, inclusive case study is presented (with multiple units of analysis, specifically three teachers) and with a descriptive research objective. The approach that is made to the phenomena is from the perspective of the actors, seeking to know their subjectivity and not the relationships that determine it. In this sense, it is based on the interpretive paradigm, which, according to Vasilachis (1992), assumes the need to understand the meaning of social action in the context of the lived experiences and from the perspective of participants.

Accordingly, taking as a reference the proposals of Bisquerra (2004), the interpretive character of this study is expressed, firstly, in the conception of reality, which is not external to the researcher, but is the result of how the researcher and the participating teachers interpret it by studying the processes that take place in the classroom and combining different points of view, personal reflections, and subjective interpretations. On the other hand, from this paradigm, human interaction constitutes the main source of the data, which is why the researcher is part of the scenario under study, 
and is involved and remains in it for a time, in order to understand and interpret everything that happens there. Finally, I used qualitative techniques that allowed me to understand the reality from an "insider" perspective, capturing the particular meaning that the participants themselves attributed to each event; all this in a process of inquiry that is no longer individual but collective, since the participants in the scenario provided data and constituted different sources of information that allowed the data to be contrasted and interpreted in the process.

\section{Participants}

Consistent with the qualitative methodology, qualitative representativeness was privileged, through the use of an intentional sample, made up of a small number of people chosen based on their relevance to the topic and the research objectives. Participants are considered key informants, as they have the possibility, the willingness and interest to demonstrate their pedagogical practices, reflect on them and refer to their experience as science teachers. In this sense, the sample of this study had the following characteristics:

- It is made up of three participants, who are teachers that run the Inquiry-Based Science Teaching (IBSE) program in the Second Cycle of Basic Education.

- Participants were evaluated by the IBSE (in Spanish ECBI) Program as "good teachers".

- Participants have shown a favorable disposition to carry out the research.

The group was expanded to eight good teachers, who participated in a process of collective reflection (group interview).

\section{Data collection techniques}

Data was collected by doing: Classroom observation (CO), which helped me to pay attention to the interaction of teachers with their students in the Science class, with inquiry-based science teaching methodology (IBSE). In-depth interviews (EP) were carried out with the participating teachers, with the aim of offering a contextualization of the research, knowing their perceptions regarding the object of study, as well as analyzing and interpreting the data obtained from the classroom observation. I also conducted a group interview (GI), in order to offer a common meeting space for the research participants, for the exchange of opinions and the negotiated consensus in the debate on the subject. 


\section{Analysis of Data}

I followed the general process of qualitative data analysis proposed by Rodríguez et al. (1999), carrying out three main tasks: Data reduction, data arrangement and transformation, generation and verification of conclusions.

\section{Research Quality Criteria}

Mendizábal (2006) proposes some quality criteria in qualitative research based on the interpretive paradigm. Accordingly, this study meets the credibility criterion, as the diverse views of the participants were recorded. I wrote notes of the facts that allowed to support the conclusions and differentiated the original data from the interpretations (commitment to field work). Along with this, I tried at all times to obtain detailed and complete information that would allow a better understanding of the subject studied (obtaining rich data), implementing various data collection techniques (triangulation). On the other hand, in relation to the security and auditability criteria, previously planned procedures and work standards were followed to obtain data, which helped me to reach to conclusions. Those who wish to access the information in this study to deeply read its conclusions or evaluate its general quality can request it by writing an e-mail to the investigating author.

\section{Limitations}

Although this research is qualitative in nature, it was carried out in a limited area and with an intentional sample chosen for its relevance. Accordingly, the number of units of analysis does not ensure the transferability of the results to other contexts with similar characteristics. It is important to note that, since it corresponds to a case study that considers three teachers, it is not possible to infer from them the characteristics of all the units not studied. On the other hand, the absence of external and internal researchers (auditors) did not allow a comparison of the results and conclusions in light of the experience and knowledge of other researchers, beyond the review of the scientific literature. However, this process was supplemented by peer evaluation prior to the publication of the scientific article. Finally, it should be mentioned that, although the methodology allowed me to achieve the proposed objectives, some of the findings and results of this study will need to be approached with a greater level of depth and detail.

\section{Results}

According to the question initially raised (What characterizes good pedagogical practices in science education?), the ability to formulate 
good questions is a finding of this study. It was found that teachers, in addition to using the question as a strategy to encourage the participation of their students in class, also used it to understand the previous knowledge of students, as well as to promote students to express themselves by sharing their ideas, experiences and intuitions, which became inputs for the class, and an opportunity to solve doubts associated with the task to be done. In each activity, teachers approached the working groups and allowed the students themselves to address them, in order to raise and resolve their concerns. In relation to this, however, it was found that the doubts and concerns of boys and girls were not always related to the content treated (about what), but rather about the procedure of the task (how): "¿How do you do this, miss?", "What goes first?" (CO1, teacher n. $\left.{ }^{\circ} 2\right)$.

Likewise, on other occasions the aesthetic quality of the work to be evaluated was emphasized more than the content (the subject matter): "It is possible with a dark [card], but it is better with a white one", "Remember that it will be evaluated the cleanliness and order of the work, it should look nice" (CO1, teacher n. $\left.{ }^{\circ} 1\right)$.

When inquiring about the strategies that teachers used to provide opportunities for students' participation, it was found that these were located on two levels: The first one was cognitive in nature, as teachers listened to the opinions of students and tried to systematize this information on the board; they usually made oral summaries of the class in order to keep the focus of students and used self-study guides as a support resource. The second one consisted on implementing strategies to favor classroom control, using various means for all students to participate, especially those with learning difficulties or disciplinary problems. For instance, one of the teachers appointed as assistants (in charge of laboratory materials) the students who they evaluated as "unmotivated or undisciplined". On the other hand, the relocation of students in the working groups and the application of unforeseen evaluations were also observed. However, although these unanticipated evaluations were observed, they constituted a regular practice of teachers, and students were aware that they could happen at any time. Teachers used to clarify the evaluation system, both in terms of content and criteria. In other words, the students knew about the topics that could be evaluated and the way it could be carried out: "Don't forget that at any time [...] we can make a short test [...] to evaluate the contents seen in the previous class" (CO1, teacher n. ${ }^{\circ}$ 3).

Furthermore, a distinctive element of good pedagogical practice is the ability to promote the growing autonomy of students. This study showed that providing opportunities to students to participate in class helped students to have an active mindset, a greater confidence when expressing 
themselves and it also strengthened their own abilities to discover things. This was reflected in two observed situations, in which the teacher's power was reduced and the child was induced to exchange and coordinate his/her points of view with other children, having the teacher on an equal status.

In the first place, the individual work of the student was observed as a regular practice, where the student investigated or prepared some material to later share, socialize and discuss with the team and the class group: "Do it individually. Do we all think the same?" (CO2, teacher n. $\left.{ }^{\circ} 1\right)$. Secondly, there were instances in which the teacher allowed autonomous group management, in which each work team had the freedom to decide the roles, functions and tasks associated with each of its members, with minimal interventions from the teacher.

Another element that was interesting to observe was how teachers reacted to student's errors. In this scenario, it was observed that one of the teachers constantly gave positive feedback to children, even when their answers were incorrect: "Ok", "Yes", "Good", "Very good", "Student: Miss, what if it's bad? Teacher: -No, why is it going to be bad?" (CO2, teacher $n .^{\circ}$ 3).

This has two opposing aspects: On the one hand, as a positive element, feeling validated helped students to foster their confidence and interest for subsequent interventions, regardless of whether their answer was good or bad. On the other hand, as a negative element, sometimes the teacher's question entailed a kind of "opinion space", where "everything was valid"; there was no teacher regulation that allowed students to move towards the socially validated answer (correct/right). In other cases, teachers accompanied their students in the search for other co-constructed solutions, using as input the conceptual clarification: "A fracture is not the same as a sprain, because..." (CO1, teacher $\left.n .^{\circ} 3\right)$.

Along the same lines, another resource used was the counter question, which, in the face of a wrong statement from students, was used by the teacher to ask a second question, as a way to activate children's thinking, thus mediating their learning: "What you just said could harm people?", "What do you think?" (CO2, teacher n. ${ }^{\circ}$ 1). One of the teachers argued how her experience changed her perception of students and the need for them to "learn that they can make a mistake, but that they also have to move on from their mistake [by showing] more confidence in asking and learning from it" (EG, teacher n. ${ }^{\circ}$ ).

Another aspect observed in this study was the teachers positive attitude towards the generation of a classroom environment that fostered a challenging environment of thought, in which discussion and exchange of ideas could take place. In this sense, teachers used discussion spaces as a 
learning strategy to foster students' capacities to listen contrasting ideas. Teachers asked questions to have contrasting opinions and to lead to thinking processes that encouraged students' argumentation capacities, based on sharing their own positions and ideas, as observed in the following excerpt: "What do you think of what your partner just said? Do you agree? Do we all think the same?" (CO2, teacher n. $\left.{ }^{\circ} 2\right)$.

In another area, regarding the use of space, time and available resources, it was found that teachers saw certain advantages of being part of the IBSE program, since it gives them access to teaching material and the laboratory, what otherwise would not be possible: "The program allows me to have teaching materials for the class", "We have resources that the school did not have before" (EP, teacher n. ${ }^{\circ} 3$ ).

Although teachers recognized that an adequate use of the available resources was of the utmost importance, this was not the only variable they considered to maintain the interest and motivation of children. For example, in relation to the use of spaces, it was observed that teachers automatically related the class with a research-based methodology space, as the spatial arrangement of the course was divided into work groups, however, in some moments of the class it was required that students listened to the teacher's explanation and not necessarily be looking at each other. This situation was observed at the beginning of a class, when the teacher posed the initial question: What is a stimulus?, she relied on audiovisual material for the explanation; meanwhile, students were distributed in groups of four people, and not all could observe the slide, and on several occasions the teacher had to ask the students for silence.

On the other hand, in relation to the use of time, although each class was planned, it was not always possible to finish it in 90 minutes: "This is homework", "We will continue next class" (CO1, teacher n. $\left.{ }^{\circ} 1\right)$.

An outstanding element, and later mentioned by teachers, is related to the vocation and commitment to the teaching-learning process:

I have a very nice relationship with children, but because I like children. I think that it's also my vocation and passion, I may sound as lacking in modesty, but I honestly think that vocation [and passion towards what we do] is everything (EP, teacher $\left.n .{ }^{\circ} 1\right)$.

This was evidenced in the interest shown by teachers in wanting their students to achieve good learning, as well as by recognizing themselves as learners in the context of the class, which requires constant preparation and concern. Such vocation, understood as an inclination and motivation towards teaching, is also related to reciprocal respect, which constitutes the 
basis for establishing a relationship of trust and closeness: "Everything begins with vocation and commitment to student learning", "Teachers must become another student" (GI, teacher n. ${ }^{\circ}$ 3).

Finally, the physical and emotional closeness promoted by teachers was shown in their attitude of trust towards the students and in the acceptance of their differences: "Come on, let's solve your doubt, ask me" (CO2, teacher n. ${ }^{\circ} 2$ ); "Are we all the same?" (CO2, teacher n. $\left.{ }^{\circ} 3\right)$.

I also observed interactions that facilitated a family work environment with freedom of expression: "In your family are everyone the same, do they all do, think, feel the same? Well, here we are like a family, but we are different "(CO2, teacher n. $\left.{ }^{\circ} 1\right)$.

As an example, one of the teachers pointed out that her change of school was due to the need to base her work not from a disciplinary perspective (control and restrictions towards students), but by emphasizing a good approach and positive contact with them. She argued: "And what about the interaction, approach and positive contact with the students?" (Gl, teacher n. ${ }^{4}$ ).

Figure 1

Elements that characterize a good pedagogical practice

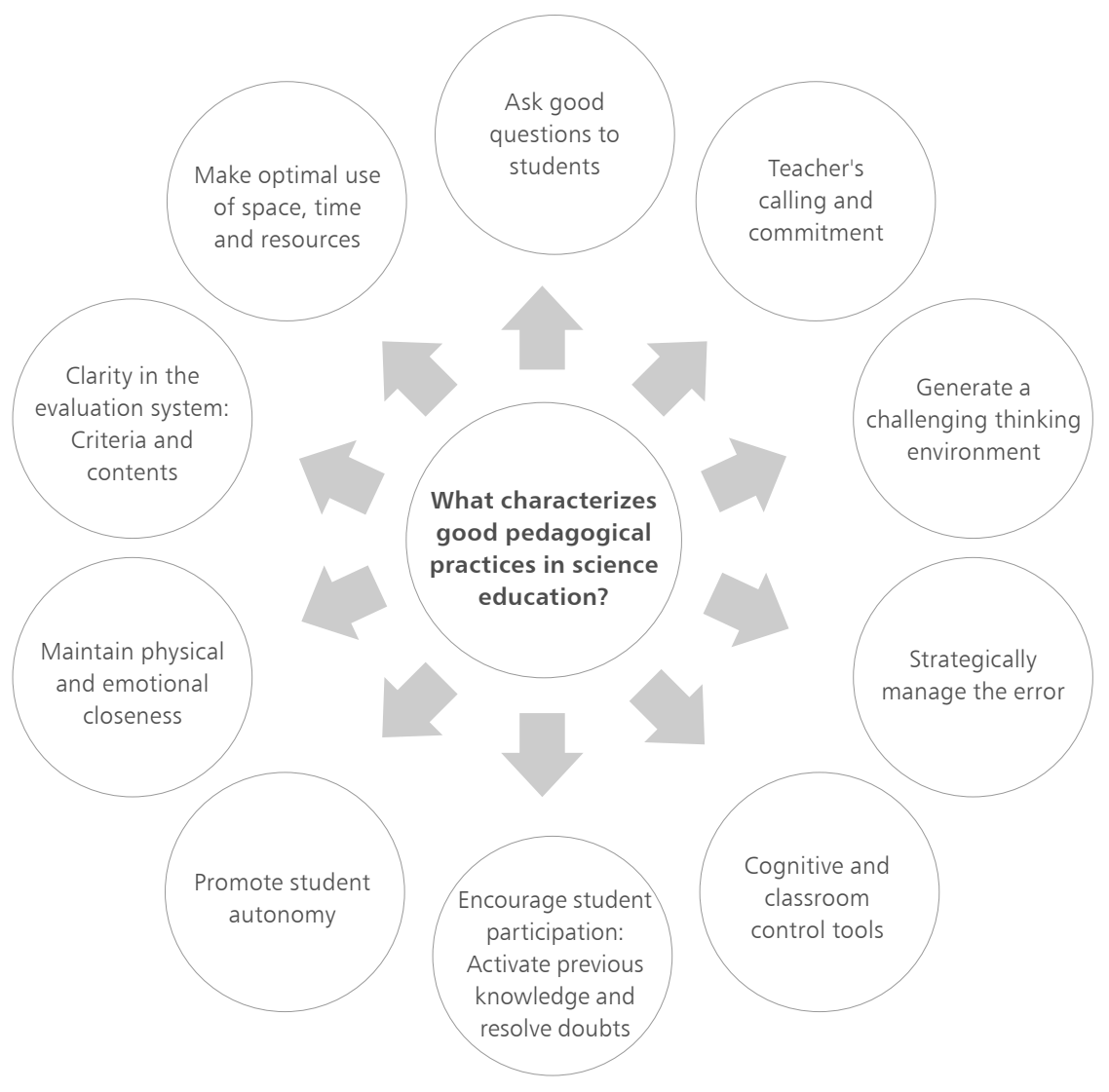




\section{Discussion of Results}

The conception of pedagogical practice considered in this study coincides with the definition of Zambrano (2018), who understands it as "those strategies, instruments and actions that the teacher performs in the classroom to guide the teaching-learning process, with the aim of developing in the student diverse competences" (p. 70). In the case of this study, competences associated with scientific knowledge and work. From this it is possible to deduce that each teacher is the one who privileges the use of some of these strategies over others, which will result in what was indicated by Rodríguez et al. (2015), who considered that the educational practice and knowledge of each teacher will generate "complex, systematic and different forms of work, going through categories that range from the magical-religious, mechanistic explanations, to relational-emergent constructions" (p. 1601).

Accordingly, this study presents some good practices, which, translated into specific strategies, could have a positive effect on teaching practice. However, its implementation must follow a permanent process of reflection, insofar as "it allows us to think about transforming practices by opening the spectrum of relationships between the subjects, knowledge and cultures involved there" (Vanegas \& Fuentealba, 2017, p. 3040). Therefore, it is necessary to generate instances in which teachers "make their previous ideas explicit and question them, generating a high level of cognitive dissonance that leads them to the construction of new meanings from a collective process" (Cortez et al., 2013, p. 848). This collective process could be observed by another, facilitating teachers to perform metacognition about their teaching and facilitating the possibility of rethinking their educational work, in order to achieve the interest and motivation of students (Zambrano, 2018).

The results shown in the previous section are related to the findings found by Veloza \& Hernández (2018) in their study of characterization and evaluation of pedagogical competences in science teaching, where they state five factors: Feedback, evaluation strategies, teaching strategies, content development and teaching resources.

\section{Participation Opportunities}

The idea that a good pedagogical practice acquires meaning only to the extent that it encourages the participation and integration of boys and girls is reaffirmed, an expression that is aligned with the Framework for good teaching (Centro de Perfeccionamiento, Experimentación e Investigaciones Pedagógicas, 2003), particularly, in the domain referring to the 
creation of an environment conducive to learning, for which "the teacher must provide opportunities for participation to all the students" (p. 13), incorporating and favoring the integration of questions, contributions and experiences of all, and not only those of the most advantaged ones.

In this sense, the paper has highlighted the importance of using various strategies that allow the participation of all students, especially those with learning or disciplinary problems. In this way, the question arises as to whether teachers should privilege the learning of the majority of the class, expelling or ignoring the students who manifest the aforementioned problems, or should they use means, strategies or resources that seek their integration. Regarding the consideration of students' previous learning as the starting point of the teaching-learning process, a constant practice observed in participating teachers was that they asked children "What do you know about that?" (in relation to the content to study), as a way to build on their ideas, experiences and intuitions, whose content supported the co-construction of knowledge in the classroom.

The aforementioned is relevant in science education, since the relationship between science and children from the beginning has been close; in fact, "if scientists and children have something in common, it is their curiosity, their desire to know and to know more; to play with the world and shake it so that all its secrets could be revelead" (Charpak et. al., 2006, p. 5). On the other hand, Ausubel (2002) argued that these practices (considering previous knowledge) are relevant for achieving significant learning by students. Learning is significant when the contents are related in a non-arbitrary and substantial way with what the student already knows, which implies on the part of teachers the ability to urge their students to evoke and share such pre-existing knowledge, whose purpose is to associate these structures with the new learning.

In relation to the doubts that students have, and the way in which teachers respond to them, it is essential that teachers could be able to clearly communicate the contents to be treated, not as definitive learning, but as learning spaces that can be subjected to judgment to generate diverse opinions in students. According to the study carried out by Veloza \& Hernández (2018), students recognize that teachers clarify doubts and concerns that arise along their classes. However, in the context of this study, it was found that students' doubts were not necessarily related to the content discussed, but rather to the procedure involved in the task to be done. In any case, when students are able to express their doubts it is evident to see, on the one hand, the confidence they have in approaching the teacher and asking about the content or procedure in question, and on the other hand, the role of the teacher as a mediator of the teaching-learning process, in 
which the teacher is exerting its influence at all times, giving meaning to the interaction. As indicated by Coll et al. (2008) the processes, mechanisms and devices of educational influence operate within the framework of joint activity or "interactivity", which is defined as the articulation of teacher's actions and their students around the task and the content, and is constructed throughout the interaction process itself.

On the other hand, this study showed that even when a question could generate interest in students, if it is about a content that is too complex or has a very high level of abstraction for their cognitive level, it is likely that their thinking processes are not activated and, therefore, significant learning may not be achieved. In this context, by not having a greater understanding of the dilemma or content discussed, students evoked their effort in the aesthetics of the work more than in the conceptual acquisition, that is, students focused on complementary evaluation criteria, such as order, cleanliness and appearance of the task, relegating conceptual content to the background. In this regard, Díaz-Barriga \& Hernández (2002) pointed out that there may be significant learning of potentially significant material, but that a student could also learn by repetition due to lack of motivation or a bad disposition, or because the student's level of cognitive maturity does not allow him/her to understand more complex content.

\section{Pedagogical Strategies}

Although the strategies could be considered as procedures that teachers, in a reflective and flexible way, use to achieve significant learning, strategies are also a means to provide pedagogical help to students, which in various situations is complex to access or perform due to the diversity in the classroom (Díaz-Barriga \& Hernández, 2002). In this study, it was observed that teachers used graphic organizers as a type of co-instructional strategy generated during class, and other technological resources to facilitate understanding of the topics; an aspect that is directly linked to the findings of Veloza \& Hernández (2018) in the factor called by them as teaching resources.

Another strategy used by teachers was the production of summaries and work guides, whose aim was to generate synthesis and abstraction of the relevant information from the class, giving importance to both the key concepts and the central principles and arguments of the discussion. Other teaching strategies are related to classroom control, such as unscheduled assessments, student relocation, and role assignment. Regarding unscheduled tests, it is important to consider what is the objective pursued, as an evaluation should allow a reflection on the teaching-learning process. Behind each decision about the evaluative task carried out by the teacher we 
find, implicitly, a certain conception of learning and, of course, of teaching (Díaz-Barriga \& Hernández, 2002). In this regard, new trends indicate that classroom management should focus on guiding students to be more competent, self-disciplined and less externally controlled (Santrock, 2006); thus, this strategy would not favor autonomy and self-regulation of students.

In relation to the above, teachers' abilities to observe and analyze class situations for the redesign of their pedagogical strategies was highlighted (Mejía et al., 2006). Teachers are considered reflective entities, who are able to propose what some authors have called a strategic teaching (DíazBarriga \& Hernández, 2002).

\section{Use of Time, Space and Resources}

Although there was evidence of a good use of the available resources, such as the audiovisual material and the equipment provided by the IBSE program, some deficiencies were observed around the use of the space and time. For instance, having empty spaces that affected the concentration and motivation of students in class. In the case of one of the teachers observed, a slow teaching style was appreciated, however, she did not coordinate properly her activities. In this regard, strategies to increase academic learning involve maintaining the flow of activities, minimizing transition time, and giving responsibilities to students (Santrock, 2006). Maintaining a flow of activity involves minimizing "sudden changes" within the classroom dynamic, as these are distracting factors, as well as responding to distractions and excessive explanations. It is suggested that one way to reduce transition time is to prepare students for future transitions, establishing transition routines and clearly defining the limits of lessons. Holding students accountable considers that if students are aware of their responsibility around their work, they are more likely to make good use of class time. A good strategy is to keep track of students' performance as a way of giving them feedback (Santrock, 2006).

\section{Clarify the Evaluation System}

The evaluation process constituted a learning instance for students. This research reflects a tendency on the part of teachers to clarify (communicate) the evaluation system. This clarification was made both in the contents and in the evaluation criteria, understanding the latter as "elements from which a comparison can be established with respect to the object of evaluation or some of its characteristics" (Ministerio de Educación, 2006, p 32). In this way, it was expected that at the time of being evaluated, students had clarity about the topics and the way in which the evaluation was going to be carried out, so that the achievement of a good grade was 
favored, which in turn promoted confidence in themselves and in their work. What additional benefit is obtained from this practice? According to the Ministry of Education (Ministerio de Educación, 2006, p. 41), "when there is an understanding of what is required to obtain learning achievements and good grades, the motivation of students increases, especially if the standards are high although possible to achieve".

\section{Conclusions}

Science is currently conceived as a fundamental element for the development and progress of societies. Therefore, science education for both children and young people has become a national concern. Accordingly, the scientific community is assuming the responsibility of collaborating in the improvement and relevance of this education. All this in a context where science does not seem to be attractive for many students, a situation that, according to Fernández-González (2008), is fundamentally due to its way of teaching, which most of the time shows a self-centered, academic and formalist image of science, which is disconnected from the everyday world.

Therefore, the need to advance towards the improvement of science education is clear, which largely depends on the change that occurs both in the teacher's vision and in the actions they carry out in their classrooms. Also, in the teacher's conviction that science is a powerful tool that contributes to children's creative development, which is possible to achieve only if students are engaged through a clear mastery of the contents and a rigorous preparation of each of the activities that teachers undertake (Allende et al., 2005).

Thus, the concept of pedagogical practice gains strength, which is understood in its most elementary sense, as everything that happens in the classroom, influenced by the personal biography, education and social beliefs of the teacher, which has a positive or negative impact in the students' experience (Fierro et al., 1999), highlighting the knowledge of the teacher (Rojas \& Zapata, 2017). These pedagogical practices are the essence of the teacher's role to the extent that they are carried out in an intentional, pertinent way and in accordance with the interests and learning needs of students.

This research contributed to the identification of pedagogical practices of outstanding female teachers in the context of science teaching. This thesis showed evidence of practices that related to the ways teachers provided students with opportunities to participate; the different pedagogical strategies they used; the use of time, space and resources, and the clarification of the evaluation system. 
Taking as a reference what was indicated by Angulo \& Álvarez (2010), a pedagogical practice not only involves teachers in their work, but also doing a reflective exercise. In this sense, moving towards a change in science education implies not only deliberately implementing good practices, such as those identified in this study, but also reflecting throughout the teaching-learning process around the role of teachers and the relevance of the implementation of these strategies.

Finally, given that there are numerous studies that show that research in teaching has little impact on educational practice, since its results are not incorporated, it is necessary to plan future research that could explain this phenomenon in such a way that the findings of this and other studies in the field of science have repercussions not only at the level of increasing scientific knowledge, but also in the improvement of pedagogical practices, to achieve a close link between research and practice. Likewise, considering the importance of teacher's reflection in the improvement of practices, it is necessary to inquire about the reflective processes of science teachers and how these processes contribute to the improvement of their practices.

\section{About the author}

Pedro Aurelio Sotomayor-Soloaga is an assistant professor at the University of Atacama, Chile, and is currently a PhD candidate in Education at the Autonomous University of Barcelona, Spain. He teaches at the undergraduate and graduate level. He is affiliated to the research lines: Teaching-Learning Processes, and Change and Improvement in Education.

\section{References}

Acevedo, J., Vázquez, A., Martín, M., Oliva, J. M., Acevedo, P., Paixão, M. F. \& Manassero, M. A. (2005). Naturaleza de la ciencia y educación científica para la participación ciudadana. Una revisión crítica. Revista Eureka sobre Enseñanza y Divulgación de las Ciencias, 2(2), 121-140. https://revistas.uca. es/index.php/eureka/article/view/3912

Agencia de Calidad de la Educación. (2015). Resultados TIMSS Chile 2015. http:// archivos.agenciaeducacion.cl/presentacion_nacional_de_resultados_TIMSS_ 2015.pdf

Aguilera, A. (2000, abril 27-29). D. E. P. I: un instrumento para la evaluación del pensamiento compartido [Conference presentation]. IX Congreso INFAD 2000, Cádiz, España.

Allende, J., Babuk, J., Martínez, S. \& Ureta, T. (2005). Análisis y proyecciones de la ciencia chilena. Academia Chilena de Ciencias.

Angulo, M. \& Álvarez, J. (2010). Tres dimensiones de la práctica pedagógica en la Facultad de Ciencias de la Educación de la Universidad de La Salle. Revista de la Universidad de La Salle, (51), 101-116. https://dialnet.unirioja.es/ servlet/articulo?codigo $=4476707$ 
Ausubel, D. (2002). Adquisición y retención del conocimiento: una perspectiva cognitiva. Paidós.

Barnett, J. \& Hodson, D. (2001). Pedagogical context knowledge: Toward a fuller understanding of what good science teachers know. Science Education, 85(4), 426-453. https://doi.org/10.1002/sce.1017

Bisquerra, R. (2004). Metodología de la investigación educativa. La Muralla.

Castro, E., Peley, R. \& Morillo, R. (2015). La práctica pedagógica y el desarrollo de estrategias instruccionales desde el enfoque constructivista. Revista de Ciencias Sociales, 12(3), 581-587. http://ve.scielo.org/scielo.php?script= sci_arttext\&pid=\$1315-95182006000300012

Centro de Perfeccionamiento, Experimentación e Investigaciones Pedagógicas (CPEIP). (2003). Marco para la buena enseñanza. Ministerio de Educación de Chile.

Charpak, G., Léna, P. \& Queré, Y. (2006). Los niños y la ciencia: la aventura de la mano en la masa. Siglo XXI.

Chirinos, N. \& Padrón, E. (2010). La eficiencia docente en la práctica educativa. Revista de Ciencias Sociales, 16(3), 481-492. https://www.redalyc.org/ pdf/280/28016320009.pdf

Coll, C., Onrubia, J. \& Mauri, T. (2008). Ayudar a aprender en contextos educativos: el ejercicio de la influencia educativa y el análisis de la enseñanza. Revista de Educación, 346, 33-70. https://dialnet.unirioja.es/servlet/articulo? codigo $=2591898$

Cortez, M., González-Weil, C., Bravo, P., Ibaceta, Y. \& Pérez, J. (2013). La investigación-acción colaborativa como herramienta para la formación continua de profesores secundarios de ciencias: problematizando las prácticas pedagógicas. Enseñanza de las Ciencias, núm. extra, 845-849. https://www. raco.cat/index.php/Ensenanza/article/view/296463/0

Creswell, J. W. (1998). Qualitative Inquiry and Research Design. Choosing among Five Traditions. Sage.

Daboin de Briceño, Z. (2008). Práctica pedagógica en la construcción del conocimiento de las ciencias naturales. REDHECS, 5(3), 77-90. https://www. google.com/url?sa $=t \& r c t=j \& q=\& e s r c=s \&$ source $=$ web\& $c d=\& v e d=2 a h U K E$ wit0Ozj6qTqAhWqg-AKHTK_B24QFjAAegQIARAB\&url=https\%3A\%2F\%2F dialnet.unirioja.es\%2Fdescarga\%2Farticulo\%2F2737349.pdf\&usg=AOv Vaw05ZDdJRBJPTJIDuQBqmMjq

Devés, R. \& Reyes, P. (2007). Principios y estrategias del Programa de Educación en Ciencias Basada en la Indagación (ECBI). Revista Pensamiento Educativo, 41(2), 115-131. https://avaconews.unibague.edu.co/wp-content/up loads/2012/11/educ-basada-en-la-indagacion.pdf

Díaz-Barriga, F. \& Hernández, G. (2002). Estrategias docentes para un aprendizaje significativo. McGraw-Hill.

Fernández-González, M. (2008). Ciencias para el mundo contemporáneo. Algunas reflexiones didácticas. Revista Eureka sobre Enseñanza y Divulgación de las Ciencias, 5(2), 185-199. https://revistas.uca.es/index.php/eureka/article/ view/3755

Fierro, C., Fortoul, B. \& Rosas, L. (1999). Transformando la práctica docente. Una propuesta basada en la investigación acción. Paidós. 
Gess-Newsome, J. \& Lederman, N. (Eds.). (1999). Examining Pedagogical Content Knowledge: The Construct and its Implications for Science Education. Kluwer Academic.

Gil, J. (2017). Rasgos del profesorado asociados al uso de diferentes estrategias metodológicas en las clases de ciencias. Revista Enseñanza de las Ciencias, 35(1), 175-192. https://www.raco.cat/index.php/Ensenanza/article/view/ v35-n1-gil

Harlen, W. (1999). Enseñanza y aprendizaje de las ciencias. Morata.

Harlen, W. \& Allende, J. (2009). Report of the Working Group on Teacher Professional Development in Pre-Secondary IBSE. Fundación para Estudios Biomédicos Avanzados de la Facultad de Medicina, Universidad de Chile.

Manchon-Gordon, A. \& García-Carmona, A. (2018). ¿Qué investigación didáctica en el aula de física se publica en España? Una revisión crítica de la última década para el caso de educación secundaria. Enseñanza de las Ciencias, 36(2), 125-141. https://doi.org/10.5565/rev/ensciencias. 2451

Manríquez, L. (2014). Algunos códigos curriculares de la actual enseñanza básica chilena. Revista Estudios Pedagógicos, 40(2), 427-440. http://dx.doi. org/10.4067/S0718-07052014000300025

Mejía, J., Orduz, M. \& Peralta, B. (2006). ¿Cómo formarnos para promover pensamiento crítico autónomo en el aula? Una propuesta de investigación acción apoyada por una herramienta conceptual. Revista Iberoamericana de Educación, 39(6), 1-16.

Mendizábal, N. (2006). Los componentes del diseño flexible en la investigación cualitativa. En I. Vasilachis de Gialdino (Ed.), Estrategias de investigación cualitativa (pp. 65-105). Gedisa.

Ministerio de Educación (Mineduc). (2006). Evaluación para el aprendizaje. Unidad de currículum y evaluación. Chile: Autor.

Pozo J. \& Gómez M. (2004). Aprender y enseñar ciencia. Morata.

Rodríguez, G., Gil, J. \& García, E. (1999). Metodología de la investigación cualitativa. Aljibe.

Rodríguez, Y., Sánchez, D. \& Silva, A. (2015). Cambio y permanencia en los fenómenos asociados a la metamorfosis, guías didácticas para niños de grado cuarto: reflexiones sobre la producción de conocimiento de los maestros de ciencias. Bio-Grafía, Escritos sobre la Biología y su Enseñanza, núm. extra, 1601-1613. https://doi.org/10.17227/20271034.vol.Onum.0bio-grafia 1601.1613

Rojas, M. \& Zapata, P. (2017). Contribuciones de la práctica pedagógica a la construcción del conocimiento profesional de profesores de ciencias en formación inicial. Enseñanza de las Ciencias, núm. extra, 413-418. https:// www.raco.cat/index.php/Ensenanza/article/view/334290

Rosas, R. \& Sebastián, Ch. (2008). Piaget, Vigotsk y Maturana: Constructivismo a tres voces ( $2 \mathrm{a}$ ed.). AIQUE.

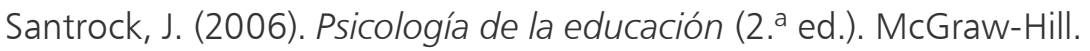

Strieder, R. Bravo, B. \& Gil, M. (2017). Ciencia-tecnología-sociedad: ¿qué estamos haciendo en el ámbito de la investigación en educación en ciencias? Revista Enseñanza de las Ciencias, 35(3), 29-49. https://doi.org/10.5565/ rev/ensciencias.2232 
Torres, A. \& Barrios, A. (2009). La enseñanza de las ciencias naturales y educación ambiental en las instituciones educativas oficiales del departamento de Nariño. Tendencias, 10(1), 143-166. https://revistas.udenar.edu.co/index. php/rtend/article/view/617

Valbuena, E. O. (2007). El conocimiento didáctico del contenido biológico: estudio de las concepciones disciplinares y didácticas de futuros docentes de la Universidad Pedagógica Nacional (Colombia) [Tesis doctoral sin publicar]. Universidad Complutense de Madrid.

Vanegas, C. \& Fuentealba, R. (2017). ¿Cuáles son las dimensiones y procesos de la reflexión del profesor de ciencias? Enseñanza de las Ciencias, núm. extra, 3039-3044. https://ddd.uab.cat/record/184023

Vasilachis, I. (1992). Métodos cualitativos I. Los problemas teórico-epistemológicos. Centro Editor de América Latina.

Velasco, A. (2007). Un sistema para el análisis de la interacción en el aula. Revista Iberoamericana de Educación, 42(3), 1-12. https://www.researchgate.net/ publication/28149588_Un_sistema_para_el_analisis_de_la_interaccion_ en_el_aula

Velásquez, S. (2012). Propuesta metodológica para la enseñanza del concepto de energía en los grados de educación media, fundamentada en el modelo de enseñanza para la comprensión [Unpublished magister dissertation, Universidad Nacional de Colombia]. https://repositorio.unal.edu.co/bitstream/ handle/unal/10403/43842731.pdf? sequence=1\&isAllowed=y

Veloza, R. \& Hernández, C. (2018). Valoración de las estrategias adoptadas por docentes en la enseñanza de la ciencia desde la perspectiva de los estudiantes de educación básica. Revista Ánfora, 25(45), 43-69. https://doi. org/10.30854/anf.v25.n45.2018.512

Zambrano, E. (2018). Prácticas pedagógicas para el desarrollo de competencias ciudadanas. Revista Electrónica de Investigación Educativa, 20(1), 69-82. https://doi.org/10.24320/redie.2018.20.1.1409 